\title{
THE ECONOMY OF ROMANIAN NAVAL TRANSPORTS IN THE PERIOD 1990 - 2000
}

\author{
Dumitru CORDUNEANU \\ “Mircea cel Bătrân” Naval Academy, Constanța, Romania \\ dumitru.corduneanu@anmb.ro
}

\begin{abstract}
This article analyses the restructuring and evolution of the most important elements of naval infrastructure which laid the base of The Economy of the Romanian Naval Transports, during the transition period: $1990-2000$.

Also, this article attempts to determine the total value of assets on the main components of the system infrastructure, following the next issues:

- Ways of Communication on the Water;

- River and Sea Ports;

- Naval Industry;

- National Merchant Fleet- river, maritime and oceanic fishing fleet.

We mention that this article is the latest in a series of four articles that analyses, in a unitary conception, the formation and evolution of the main elements of the Naval Transportation System of the last century, at the level of four reference periods: the pre-war period (1900-1914); the interwar period (1919-1939); socialist period (1950-1990) and transition period (1990-2000).
\end{abstract}

\section{Keywords: naval transport, riverine fleet, maritime fleet, naval industry}

\section{Introduction}

The period 1990-2000, from the point of view of the accumulation of capital and the development of the economic potential not only for the Romanian Naval Transport System, but for the entire national economy constituted a period of regress due to the profound economic, political and social crisis with which Romania will face after the revolution of December 1989 and triggering the transition from the Centralized Economic System to the Market Economy System.

\section{Evolution of the Romanian Naval Transports in the Period 1990-2000}

Although important rights have been earned at the social level, regarded as undeniable values of democracy, such as freedom of expression, access to information, the free movement of persons as a result of the opening of borders and the exit from the isolation in which we have lived for approx. 4 decades, ownership of property, etc., all these were strongly shaded by the dramatic fall of the economy, the amplification of the economic gaps towards the developed states, the drastic deterioration in the income of most of the population, the decrease in purchasing power due to the rising growth of prices, rising unemployment and alarming escalation of poverty.

Compared to 1989, until the end of the period we refer to, national production has fallen by $38.4 \%$, industrial production with 
$56.3 \%$, agriculture with $14.2 \%$, exports with approx. 18.9\% and GDP (Gross Domestic Product) by $26.4 \%$ [1].

In absolute terms, these losses amount to approx. 347.76 billion dollars, with an average annual rate of about 34.76 billion dollars, Romania's national production at the end of this period equaling that of 1975 , our country being thrown back almost a quarter of a century, enormously increasing economic gaps over the developed worlds, which so, compared with the EU (European Union) member states registered in 1989 an economic delay of approx. 6 decades [2].

Table 1. Economy of Romanian Naval Transports, per components in the period 1990-2000

\begin{tabular}{|c|c|c|}
\hline \multirow{2}{*}{ Item } & \multirow{2}{*}{ Components } & \multirow{2}{*}{$\begin{array}{c}\text { Millions of dollars } \\
1990-2000\end{array}$} \\
\hline & & \\
\hline 1 & $\begin{array}{l}\text { Fluvial Ports and Navigable Roots, including } \\
\text { Navigable Channels }\end{array}$ & 37.10 \\
\hline 2 & Maritime Ports and Navigable Roots & 860.22 \\
\hline 3 & Naval Industry & 378.70 \\
\hline 4 & Fluvial Fleet & 70.27 \\
\hline 5 & Maritime Fleet & 240.54 \\
\hline 6 & Fishing Fleet & 17.06 \\
\hline 7 & Naval Radio-Communication System & 0.36 \\
\hline & TOTAL ASSET & $1,604.25$ \\
\hline
\end{tabular}

Source: PhD. eng. Dumitru Corduneanu, The System of the Naval Transport from Romania in the XX century, CTEA Publishing House, Bucharest 2010, p. 343

At a social level, the real incomes of the population almost halved, decreasing by approx. $41.4 \%$, the unemployment rate increased from $3 \%$ in 1990 to $12 \%$ in 2000 , which led to the loss of approx. $45 \%$ of the original jobs $(8,150$ thousand employees to 4,480 thousand employees), and according to the calculation methods applied by the World Bank and the OECD (The Organization for Economic Cooperation and Development), the poverty rate increased alarmingly from 6\% in 1989 to an absolute poverty of approx. $30 \%$ and relative poverty of approx. $40 \%$ at the end of the 20th century [3].

In the "Transition harder than a war", following the researches made, the author reaches a striking and at the same time regrettable conclusion: "If after the two world wars, with their massive destructions and long-term consequences, the pre-war economic levels were restored in approx. 56 years, in the last decade of the 20th century, the Romanian economy was in a free fall, being far from the economic achievements registered in 1989" [4].

Evolving under such economic, social and political conditions it would have been "abnormal" that the situation in the Romanian Naval Transport System was different. Indeed, during the period we refer to, within the Naval Transport System in Romania, there is a dramatic decrease of the most technical and economic indicators for the measurement of the shipping activity, in parallel with the process of decapitalization of the Maritime Trade Fleet and the Oceanic Fleet and the inevitable bankruptcy of these, that will occur by the end of the 20th century, this time the country's maritime tonnage was virtually liquidated and the expeditionary fishing activity was non-existent.

If the other components of the System, after overcoming the shock of decentralization, succeed in adapting to the new economic 
conditions, reaching a certain economic equilibrium, the economic, structural and managerial difficulties faced by the Maritime Trade Fleet and Ocean Fleet have proved to be insurmountable.

From the patrimonial point of view, at the end of the 20th century, the Total Assets of the Component System were as follows [5].

The Ports and the Navigable Routes had about 897.32 million dollars, out of which Fluvial Ports and Navigable Roots - 20.94 million dollars, Maritime Ports and Maritime Routs - 860.22 million dollars, and Navigable Channel Administration 10.17 million dollars.

On the same date, the Naval Industry had a heritage valued at 378.70 million dollars, of which the 12 Shipyards had a total asset of 313.03 million dollars; the 4 shipbuilding factories - 62.95 million dollars; Naval Research Institute (ICEPRONAV-Galati) 1.72 million dollars, and the Romanian Naval Register's assets amount to approx. 0.30 million dollars.

At the end of the 20th century, the National Civilian Fleet had a Total Asset valued at 327.87 million dollars, of which [6]:

- the Fluvial Fleet had an asset of 70.27 million dollars, of which 56.80 million dollars were fixed assets and 11.44 million dollars of current assets;

- only one year after the initiation of the partial operational closure procedure of the ROMLINE and PETROMIN Maritime Navigation Company and of the judicial liquidation of NAVROM Maritime Navigation Company, the Maritime Fleet was still with a total asset of 240.54 million dollars, of which the fixed assets amounted to 24.76 million dollars, and the current assets amounted to 49.77 million dollars;

- on the same date, the Fleet's own capital accounted for approx. 12.90 million dollars, and the remaining debt - after a portion was extinguished to the creditor mass by ship sales - amounted to 88.93 million dollars, the leverage amounting to approx. $37 \%$ in total active and approx. 7 times the existing equity. From the data presented above, it is observed that in just 10 years the value of the fixed assets reaches 3,049 billion dollars, existing at the beginning of 1990 , to 25 million dollars at the end of 2000, a decrease of 123,14 times, which represents approx. $0.81 \%$ of the value recorded in the reference year. Correspondingly, the amount of the Fleet Maritime debt reaches 110 million dollars in 1999, or 89 million dollars in 2000, up 4 times, or 3.06 times as compared to 1 January 1990, of approx. 29 million dollars;

- in the case of the Ocean Fishing Fleet, the situation was even worse in the sense that since the bankruptcy proceedings of 1988, its total assets amounted to 17.06 million dollars, of which fixed assets amounted to 1.09 million dollars and current assets 6.90 million dollars. On the same date, the equity of the Ocean Fishing Fleet became negative - 4.77 million dollars, and the remaining debt amounted to 11.68 million dollars. 


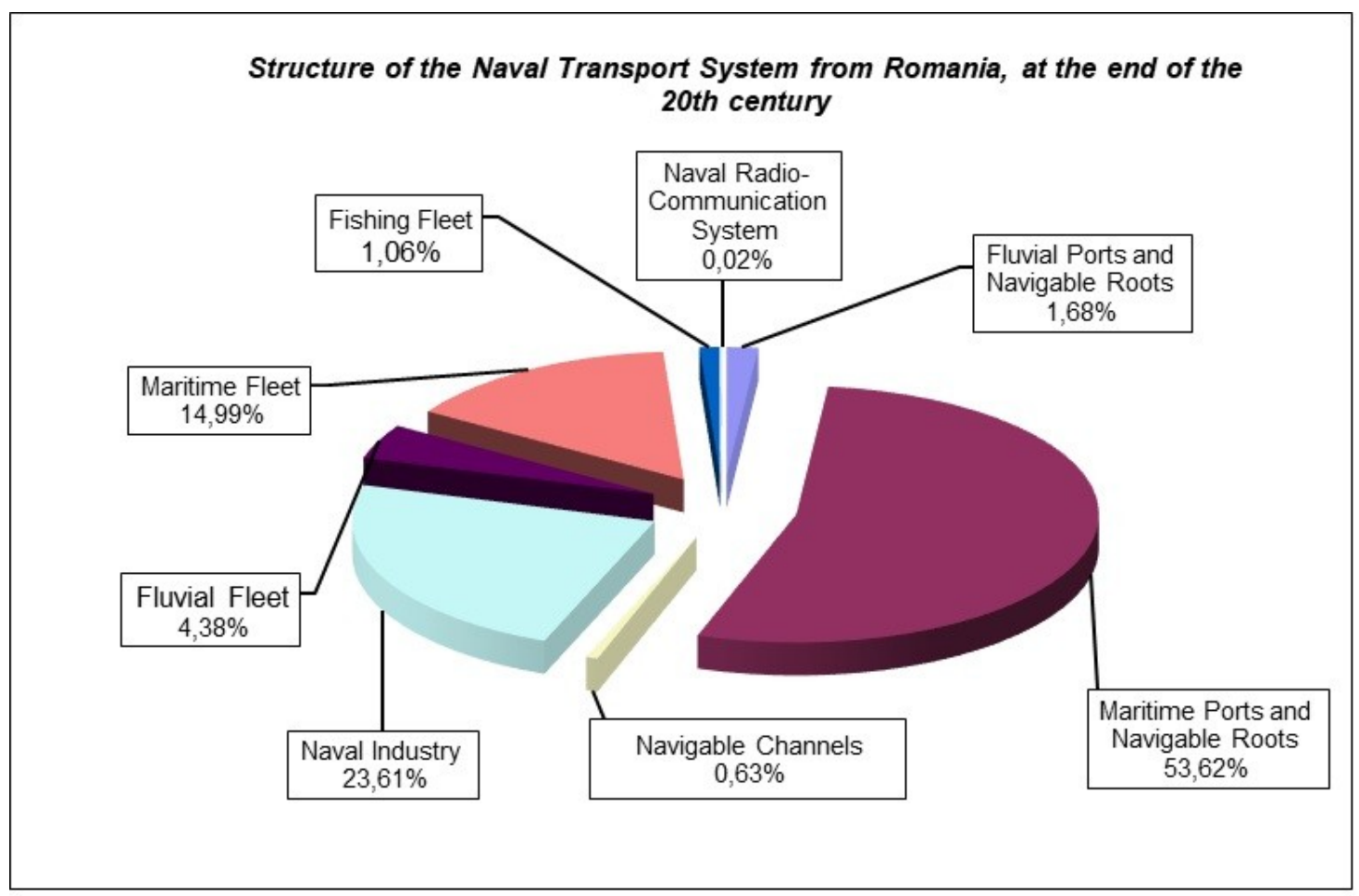

Figure 1: Based on the data in the Table 1

Accumulating the data presented above, we find that at the end of the analyzed period, the Naval Transport System in Romania also had a real capital of approx. 1,604.25 million dollars, of which the fixed capital stock amounted to 1,107.02 million dollars and the circulating capital of approx. 395.78 million dollars, the System recording against the previous period, a decrease in the Total Asset of approx. 5 times that induced a loss of approx. 3.76 times in the case of immobilized assets and approx. 1.74 times in the case of the circulating ones, structured on components according to Figure 1.

Therefore, we find that total assets of the system at the end of the century is much lower than that of 1990. This is due mostly to losses of active elements following the bankruptcy of Maritime Transport Fleet and Ocean Fishing Fleet estimated at least 3.3 billion dollars and that for this period last were not considered part of private companies set up in the system after 1990, and especially in the field of ports and waterways, where the divided heritage was given the administration of these private companies [7].
As can be seen in the System is a new item of infrastructure - Naval Radio Communication System, with special importance in the development and optimization of information needed to carry out activities of shipping, but it is not in itself a new investment objective achieved after 1990 and it was established by reorganizing the radio traffic department of the former Navrom Company, however had to emphasized that the equipment that was provided during this period is more modern than that which existed before 1990 .

At international level, in the period 1990 2000, World Maritime Square, recorded important achievements, which are due to economic growth in this period global GDP registering average annual rate of approx. $2.6 \%$. Groups of countries, these increases were obviously different countries with developed economy registered an average annual growth rate of $2.3 \%$, EU - $2 \%$, which of: Germany - 1.9\%, France $-1.7 \%$, Italy - $1.5 \%$, UK - $2 \%$, developing countries - 3.9\% US - Japan 3.4\% - 1.3\%. But of all countries, the most growth will record China - 10.1\%, opposite the 
transition countries which experience negative growth of $-2.6 \%$ [8].

This evolution of the global economy will lead to a trend in the same direction of international trade, only in the past year exports of goods increased by $9.9 \%$ and imports by 9.6 percent. This has resulted in a corresponding increase in the volume of goods transported by sea, with $469.96 \%$, from 4 billion tons in 1990 to 5.59 billion tons at the end of twentieth century [9], the countries with developed economy took $42.5 \%$, the countries of Central and Eastern Europe - $4.6 \%$ and emerging countries $50 \%[10]$.

In terms of transport capacity of the world fleet, it recorded an increase of $21.23 \%$ from 666.80 million to 808.38 million dwt, average age of the world fleet located at 14 years, the world fleet structure on the following types of vessels: tankers $-35.4 \%$, bulk carriers and ore $-34.6 \%$, general cargo goods - 12.7\%, special vessels (container and liquefied gas ships, etc.) - 20.5\%, passenger ships $-0.6 \%$ other $-5.5 \%$, not much different from our maritime floating structure in the 1990s [11].

In terms of productivity World Fleet in the last decade of the twentieth century, the index of transport capacity utilization stood around 6.5 - a difference only five tenths of the productivity of our marine fleet an average value 6, before 1989 [12].

\section{Conclusions}

In the last decade of the twentieth century, due to a cumulus of factors, some explainable others questionable, the Romanian Maritime Trade Fleet goes bankrupt, and we find that in just 10 years, after a century of transformations and economic transformations, the Maritime Transport Fleet is thrown back on the axis of time, near the point where it left.

\section{References}

[1] Nicolae Belli, Transition harder than a war, Expert Publishing House, Bucharest, 2001, p. 55.

[2] Ibidem, p. 58.

[3] Ibidem, pp. 113, 210, 242, 261.

[4] Note: according to the same author, the year of the greatest economic conjuncture before 1989 was 1987 , but due to the social and political connotations that characterize it, 1989 is taken as the reference year by most researchers.

[5] PhD. eng. Dumitru Corduneanu, The System of the Naval Transport from Romania in the XX century, CTEA Publishing House, Bucharest 2010, p. 345.

[6] Ibidem.

[7] Note: only in the field of goods operation, at the level of 2000, they acted approx. 40 companies with only port superstructure assets, the infrastructure elements being in the Port Administration.

[8] UNCTAD, Review of Maritime Transport, New York 2001, p. 2.

[9] Valentin Stan, Treaty of Maritime Transport, Bucharest, 2003, p. 122.

[10] UNCTAD, op. cit., p. 11.

[11] Dumitru Corduneanu, op. cit., p. 142.

[12] Ibidem, p. 251.

[13] Bosneagu, R., Coca, C., E., Sorescu, Fl., World Economy and World Seaborne Trade in the 2005-2013 Period, EIRP Proceedings, Vol. 9, European Integration - Realities and Perspectives, 2014, pp 236-239. 